\title{
KEADILAN BAGI MAGDA: MENEMUKAN KEMBALI IMPULS TEOLOGI DAN PASTORAL PEMBEBASAN
}

\section{Ronald Helweldery}

\author{
Dosen STT GPI Papua \\ Sekretaris Badan Pekerja Sinode GPI Papua. \\ Email: helwederyronald@gmail.com
}

\begin{abstract}
Church pastoral service, both in practical and academical, tend to be treated as a subfield service and study. Meanwhile, the problems that has been faced by people become complicated. The traditional pastoral approach abandon the complexity of social-historical life of the people. Domestification and individualism of pastoral service has been dominating. According to pastoral activity, Author tries to revive what is called pastoral for liberation or critical pastoral. This came from theological impulse and education for liberation. The explanation aim to encourage a new perspective and a new mode of pastoral service.
\end{abstract}

Keywords : Pastoral activity, child protection, Theology of liberation, pastoral education and pastoral for liberation

\begin{abstract}
Abstrak
Pelayanan pastoral gereja, baik dalam praktik maupun akademik, cenderung diperlakukan sebagai bidang pelayanan dan kajian pinggiran. Sementara, persoalan-persoalan yang dihadapi umat makin rumit. Pendekatan pastoral gereja tradisional mengabaikan kompleks itassosio-historik kehidupan umat. Domestikasi dan individualisme pelayanan pastoral masih begitu dominan. Bertolak dari satu peristiwa pastoral, penulis berusaha mengangkat kembali apa yang disebut pelayanan pastoral pembebasan atau kristis. Usaha kecil ini bersumber dari impuls teologi dan pendidikan pembebasan. Paparan ini dimaksud untuk mendorong penyegaran perspektif dan model baru praktik pelayanan pastoral.
\end{abstract}

Kata Kunci : Peristiwa Pastoral, perlindungan anak, Teologi pembebasan, pendidikan dan pelayanan pastoral pembebasan

\section{A. PENDAHULUAN}

Gereja hadir secara nyata dan praktis dalam konteks kehidupan sehari-hari umat di lingkup jemaat-jemaat lokal. Namun, gereja masih menghidupi kultur hierarkis. Buahnya adalah pendekatan atas-bawah yang sangat dominan. Secara 
khusus, para pelayan jemaat lokal lebih berpikir dan bertindak sebagai aparatus formal gereja, sebagai bagian dari hierarki dan otoritas gereja. ${ }^{1}$ Kondisi ini berdampak pada praksis pelayanan pastoral jemaat. Persoalan-persoalan sistemikstruktural yang menjadi konteks reproduksi kehidupan keseharian masyarakat dan umat tidak menjadi fokus utama. Segala sesuatu bersegera dispiritualisasikan dalam langgam domestikasi. ${ }^{2}$ Kajian-kaijian sosio-historik hampir tidak mendapat tempat dalam pengembangan praksis kehadiran gereja. ${ }^{3}$

Gereja butuh stimulan kritis untuk mengembangkan model berteologi dari bawah bersama umat dalam konteks pergulatan kehidupan sehari-hari mereka dalam konteks sistem dan interalasi serta praktik sosial. Untuk itu, kita patut melihat kembali relevansi impuls model berteologi pembebasan atau praksis ${ }^{4}$ dalam kaitan dengan kiprah pastoral gereja pada level jemaat lokal. ${ }^{5}$ Paparan ini akan diawali dengan satu peristiwa pastoral dalam menegakkan hak asasi seorang gadis bernama Magda di sebuah jemaat kampung. Peristiwa pastoral tersebut selanjutnya dibawa masuk ke dalam pewacanaan reflektif, terkait dengan perlibatan aspek legal dalam karya pastoral jemaat lokal. Pelibatan aspek legal ini tidak hanya dalam rangka deskripsi tetapi juga analisis situasi sosial. Pewacanaan tersebut mengangkat ke permukaan spirit dan etik pembebasan terkait dengan isu-isu seperti kekerasan, diskriminasi, perampasan kemerdekaan, penelantaran, dll.

Selanjutnya, paparan ini akan diarahkan untuk menemukan dan mengangkat kembali impulsi teologi dan pendidikan pembebasan sebagai basis perspektif pengembangan pastoral pembebasan. Tulisan ini dimaksudkan untuk mendorong penyegaran perspektif dan pemikiran-ulang model serta praktik pendidikan dan pelayanan pastoral.

\section{B. KEADILAN UNTUK MAGDA :SUATU PERISTIWA PASTORAL- SOSIAL $^{6}$}

Magda dilahirkan dan dibesarkan dalam lingkup masyarakat pedesaan yang masih menjunjung tata nilai dan sistem adat. Magda lahir dari seorang ibu yang diperkosa oleh seorang lelaki. Lelaki tersebut adalah salah satu pekerja pada proyek pembangunan jalan yang melintasi kampung ini. Lelaki ini kemudian melarikan diri. Ibu Magda sendiri mempunyai cacat bawaan fisik pada pundak (bungkuk). Selama beberapa tahun, Magda hidup dengan ibunya tanpa tempat tinggal yang tetap. 
Setelah melahirkan Magda, kesehatan ibunya makin menurun, sampai akirnya meninggal dunia saat Magda berusia lima tahun. Magda hidup sebagai seorang anak yatim piatu. Kemudian, Magda tinggal bersama seorang pamannya, tetapi tidak lama kemudian, sang paman mengusir Magda keluar dari rumahya hanya karena Magda memakan ikan goreng yang disiapkan untuk sang paman. Melihat kondisi Magda yang sangat memprihatinkan, seorang sepupunya kemudian menyampaikan dan meminta kepada orangtuanya untukmengajak Magda tinggal dengan mereka. Sejak saat itu, Magda hidup dalam perlindungan dan pengasuhan keluarga ini.

Orangtua asuh Magda adalah anggota Majelis Jemaat setempat, yang mengasihi dan memperlakukan Magda seperti anak kandung. Magda diasuh dengan disiplin bersama sepupu-sepupunya dalam keluarga ini. Namun, perjalanan hidup Magda tidaklah mulus. Ketika masih di tingkat akhir Sekolah Dasar, seorang pamannya yang lain telah mempersiapkan calon suami baginya. Tata adat setempat, yang menganut sistem perkawinan patrilineal, menempatkan saudara lelaki dari ibu/istri [paman] pada posisi penting dan memegang otoritas keadatanmenentukan atas hidup keponakan-keponakannya. Magda dipaksa untuk berhenti sekolah dan dipersiapkan untuk menerima lamaran pernikahan. Bagi mereka, anak perempuan tidak perlu bersekolah yang tinggi. Magda yang masih anak-anak ini tidak berdaya dan pasrah. Interupsi ini menciptakan ketegangan antara paman yang sementara mengasuh dan membesarkan Magda dengan paman lain yang memutuskan agar Magda segera dinikahkan saja. Ketegangan ini melibatkan pula pendeta jemaat setempat. Pendeta selama ini menjadi mentor atau pembimbing bagi Magda serta anak-anak perempuan lainnya.

Pertemuan adatpun diadakan antara keluarga-keluarga paman Magda. Suasana menegang dan percakapan menjadi sangat keras karena perbedaan pendapat dan pilihan keputusan. Pendeta dan kedua orangtua yang mengasuh Magda akhirnya menyatakan pandangan dan sikap mereka. Pendeta menyatakan dengan tegas dan berani bahwa bila Magda tetap dipaksa untuk berhenti sekolah dan menikah, mereka akan melaporkan masalah tersebut ke pihak kepolisian. Pendeta mendasarkan sikap ini pada hak asasi anak yang harus dilindungi, antara lain oleh keluarga sendiri. ${ }^{7}$ Tantangan tegas itu membuat paman Magda yang sebelumnya bersikeras agak mereda. Mereka khawatir terhadap efek hukumannya. Pada momen itulah, pendeta 
melanjutkan pembicaraan bahwa Magda wajib bersekolah setinggi-tingginya sesuai dengan cita-citanya. Dengan demikian, kelak bila tiba waktunya untuk menikah, Magda sudah siap membangun masa depan dalam kehidupan berkeluarga. Kedua pihak keluarga akhirnya menyetujui keputusan ini.

Di sekolah, Magda tergolong anak yang cerdas. la menjalani pendidikan Sekolah Dasar (SD) dan Sekolah Menengah Pertama (SMP) di kampung dengan prestasi yang bagus. Magda mengikuti Olimpiade Matematika Tingkat Kabupaten sebagai salah satu utusan dari SMP-nya. Karena berprestasi baik, Magda masuk Program Afirmasi bidang pendidikan bagi Putra-Putri Asli Papua. ${ }^{8}$ Dengan biaya Permerintah Daerah, ia melanjutkan pendidikan menengah atas pada salah satu sekolah di Kota Semarang. Magda berhasil menyelesaikan Sekolah Menengah Atas (SMA) pada tahun 2016. Kini Magda melanjutkan studi di Universitas Negeri Semarang (UNES).

Perlu diperhatikan bahwa sejak memulai tugas pelayanan di jemaat kampung ini, pendeta telah meletakkan visi dasar pelayanannya yang berpusat pada pendidikan dan pendampingan pastoral bagi anak dan remaja. Visi ini membawa pendeta untuk secara serius memperhatikan dan memperkuat intensitas serta mutu pelayanan anakremaja dalam jemaat ini. Penetapan fokus pelayanan ini memang dikondisikan oleh realitas sosial kehidupan anak dan remaja di kampung ini. Perhatian keluarga dan masyarakat terhadap anak-anak sangat rendah. Anak dan remaja banyak yang putus sekolah serta menikah di usia dini. Tingkat pendidikan dan melek huruf sangat rendah, ${ }^{9}$ begitu pula dengan kondisi lembaga pendidikan formal yang ada di kampung. Penyelengaraan pendidikan tidak berjalan dengan baik, sehinggapendidikan dalam jemaat, seperti Sekolah Minggu, menjadi tempat alternatif yang menarik bagi anak dan remaja di kampung ini.

\section{HAK ASASI DAN PERLINDUNGAN ANAK : PELIBATAN ASPEK LEGAL DALAM PELAYANAN PASTORAL ${ }^{10}$}

Peristiwa pastoral ini terkait langsung dengan perihal hak asasi dan perlindungan anak yang diatur dalam Undang-Undang Republik Indonesia. ${ }^{11}$ Pendeta dan orang tuaasuhtelah mengindikasikan hal ini dalam proses pastoral memperjuangkan keadilan untuk Magda. Mereka telah merepresentasikan institusi gereja dan keluarga yang sadar hak asasi dan perlindungan anak. Pihak paman yang 
memaksa Magda untukberhenti sekolah dan menerima peminangan pernikahan usia dini secara terang telah melakukan kekerasan. Realitas kekerasan terhadap anak ini merupakan fenomena kekerasan struktural-kultural. ${ }^{12}$ Kekerasan itu dilakukan secara sadar dengan dalih otoritas adatis. Kekerasan itu dilakukan dari dalam posisi sosialkultural yang bersangkutan. Kekerasan terhadap anak ini berlangsung dalam tatanan sistem dan struktur sosial yang ada dan di pandang wajar. Kekerasan strukturalkultural mana sesungguhnya berakar dalam dehumanisasi dan berujung pada perampasan kemerdekaan anak. Undang-Undang Perlindungan Anak Pasal 1:15a menyatakan bahwa;

Kekerasan adalah setiap perbuatan terhadap anak yang berakibat timbulnya kesengsaraan atau penderitaan secara fisik, psikis, seksual, dan/atau penelentaran, termasuk ancaman untuk melakukan perbuatan, pemaksaan, atau peramapasan kemerdekaan secara melawan hukum.

Pihak paman yang berkeras dengan manipulasi hak adat perkawinan dibawa kepada proses penyadaran akan kekerasan dan diskriminasi serta dehumanisasi yang ia sementara lakukan terhadap ponakannya. Melalui proses debat pastoral yang berlangsung, semua pihak dibawa kepada pemahaman dan kesadaran terkait dengan hak anak serta perlindungan anak. Anakanak memiliki dan membawa dalam diri serta kehidupan mereka hak asasi. Hak asasi built-in dalam kedirian dan sejarah kehidupan mereka. Hak Anak oleh Undang-Undang Pelindungan Anak Pasal 1 ayat 12 dirumuskan demikian:

Hak anak adalah bagian dari hak asasi manusia sebagai asasi anak yang wajib dijamin, dilindungi, dan dipenuhi oleh orang tua, keluarga, masyarakat, negara, pemerintah dan pemerintah daerah.

Pasal ini secara jelas menegaskan bahwa semua pihak dalam kehidupan masyarakat (orang tua dan keluarga serta masyarakat, negara dan pemerintah) bertanggungjawab penuh dalam hal perlindungan anak.

Sebelumnya Undang-Undang Perlindungan Anak Pasal 1 ayat 2 merumuskan hakikat dan makna dari pelindungan anak secara mendasar dan jelas demikian:

Perlindungan anak adalah segala kegiatan untuk menjamin dan melindungi anak dan hak-haknya agar dapat hidup, tumbuh, berkembang, dan berpartisipasi secara optimal sesuai dengan harkat dan martabat kemanusiaan, serta mendapat perlindungan dari kekerasan dan diskriminasi. 
Penghormatan terhadap hak anak didasarkan pada paham dan penghayatan akan anak sebagai subyek historik berharkat dan bermartabat dalam kemanusiaan (humanitas)nya. Itu berarti perlindungan anak adalah bagian dari usaha humanisasi, memanusiakan anak untuk dapat hidup, tumbuh, berkembang dan berpartispasi dalam kehidupan masyarakat. Untuk itu, anak-anak harus dilindungi dari kekerasan, dehumanisasi, dan perampasan kemerdekaan .

Undang-Undang ini memaklumatkan kewajiban dan tanggungjawab semua komponen. Di sini secara khusus akan ditunjukkan kewajiban dan tanggungjawab orangtua serta keluarga sebagaimana tertuang dalam UU Perlindungan Anak. Pasal 26 ayat 1 memaklumatkan demikian:

Orang tua berkewajiban dan bertanggungjawab untuk: a. mengasuh, memelihara, mendidik, dan melindungi anak; b. menumbuh kembangkan anak sesuai dengan kemampuan, bakat, dan minatnya; c. mencegah terjadinya perkawinan pada usi dini; dan d. memberikan pendidikan karakter dan penanaman nilai budi pekerti pada anak.

Sebelumnya dalam Pasal 13 (1) dan (2) ditegaskan tentang hak anak atas perlindungan dan akibat hukum bagi pelanggar demikian

(1) Setiap anak selama dalam pengasuhan orang tua, wali, atau pihak lain manapun yang bertanggungjawab atas pengasuhan berhak atas pengasuhan berhak mendapat perlindungan dari perlakuan

a. diskriminasi;

b. ekspolitasi, baik ekonomi maupun seksual;

c. penelantaran;

d. Kekejaman, kekerasan, dan penganiayaan;

e. Ketidakadilan; dan

f. Perlakuan salah lainnya.

(2) Dalam hal orang tua, wali, atau pengasuh melakukan segala bentuk perlakuan sebagimana dimaksud dalam ayat (1), maka pelaku dikenakan pemberatan hukum.

Introduksi Undang-Undang Perlindungan Anak dalam persitiwa pastoral ini telah membantu secara menentukan dalam mengungkap realitas ketidakadilan dan diskriminasi yang dialami oleh anak-anak di lingkungan jemaat dan masyarakat kampung. Itu membantu orang tua dan keluarga serta masyarakat memahami kondisi 
terberi merupakan reproduksi sosial-kultural yang didalamnya mereka berperan aktif dan harus bertanggungjawab. Reproduksi sosial sedemikian membentuk lingkaran setan yang di dalamnya anak-anak harus hidup. Perstiwa pastoral di atas berpokok pada fenomena kawin usia dini yang hampir umum di kampung-kampung. Perkawinan dini mengakibatkan berbagai persoalan yang harus dihadapi, seperti putus sekolah, tingkat pendidikan yang sangat rendah, buta aksara, kesehatan biologis dan psikologis, kemiskinan, kekerasan dalam rumah tangga, dll. Lingkaran setan reproduksi sosial ini harus diputuskan melalui pelayanan pendidikan dan pastoral pembebasan.

\section{MENEMUKAN KEMBALI IMPULSI TEOLOGI DAN PENDIDIKAN SERTA PASTORAL PEMBEBASAN}

Pendeta dan orangtua asuh telah merepresentasikan institusi gereja dan keluarga yang sadar hak asasi dan perlindungan anak. Mereka telah dengan berani memasukkan dan mengemukakan aspek hukum negara, yang merupakan bagian dari perubahan sosial, dalam konteks pelayanan pastoral perlindungan anak. Pclayanan pastoral telah menjadi momen praksis advokasi hak-hak anak berdasarkan hukum negara. Dengan ketegasan dan keberaniannya, pendeta (mewakili gereja) telah melakukan usaha pelayanan penyadaran (konsientisasi) umat. Pendeta jernaat dan keluarga terkait telah memulai usaha menanamkan kesadaran kritis-transformatif dalam kehidupan umat. Upaya ini memang tidaklah mudah, karena dilakukan dalam konteks perhadapan dengan kecenderungan bias atau manipulasi otoritas adat setempat. Disadari atau tidak, pendeta jemaat dan keluarga terkait sudah memulai model berteologi dan pelayanan pastoral pembebasan. Mereka telah memulai proses dan usaha memutuskan mata rantai lingkaran setan reproduksi sosial yang pincang dan tidak adil tersebut.

Teologi pembebasan menegaskan bahwa beriman adalah proses mengambil bagian dalam pergulatan kehidupan sehari-hari manusia. Berteologi merupakan jalan memasuki, menghidupi, dan menggumuli realitas sosial, budaya, politik, dan ekonomi di bawah arahan iman dan Firman Allah. Berteologi, dengan kata lain, adalah berjalan mencari dan menemukan Allah, dan mewujudkan maksud Allah dalam perjuangan dan pergulatan kehidupan sehari-hari. Oleh karena itu, yang menjadi locus atau medan berteologi adalah praksis, yaitu: Aktivitas-aktivitas 
partisipatif dan perjuangan individu dan kolektif manusia dalam mengubah dan merekonstruksi tatanan kehidupan mereka monjadi lebih baik dan layak. Mereka ini adalah kaum yang absen selama ini dari masyarakat dan gereja kita. ${ }^{13}$ Mereka adalah masyarakat akar rumput yang tidak berdaya dan rentan. Mereka adalah kaum miskin, orang kecil yang dipandang tidak penting. Mereka tidak berkesempatan untuk mengekspresikan penderitaan-penderitaan, rencana-rencana dan harapan-harapan mereka sendiri, termasuk di sini adalah anak-anak. Kini, mereka muncul secara mendesak ke tengah panggung sejarah dan menjadi pusat subjektif dari karya kehadiran gereja dalam masyarakat. ${ }^{14}$ Mereka muncul di pusat kesadaran gereja dan masyarakat.

Interupsi masyarakat akar rumput ini menggugat dan menggugah gereja untuk secara sadar mengambil bagian dalam kehidupan mereka. Gereja, dalam terang iman, memilih bersolidaritas dengan masyarakat atau komunitas akar rumput. ${ }^{15}$ Keberpihakan ini adalah komitmen praksis gereja untuk berjuang melawan prosesproses dehumanisasi masyarakat yang dilakukan oleh kekuatan-kekuatan dalam dan luar masyarakat. Keberpihakan gereja ini diwujudkan melalui posisi dan peran kependetaan serta keluarga jemaat lokal. Pengalaman menggereja menunjukkan bahwa kependetaan adalah komponen intelektual atau kaum cerdas yang menempati posisi dan peran publik strategis, baik dalam gereja maupun masyarakat. Sepatutnya kependetaan menghidupi etos intelektual organik yang diperkenalkan oleh Gramsci. ${ }^{16}$ Dengan begitu, kita bisa memahami kependetaan sebagai model kehadiran partisipatif-empatik dalam kehidupan praktis masyarakat. Pendeta tidak datang sebagai orang asing dan berdiri di luar atau di atas pengalaman hidup masyarakat yang dilayani. Pendeta bukanlah pembakar dan penggerak perasaandan semangat umat sesaat melalui khotbah atau pidato rohani. Pendeta, sebagai intelektual organik, adalah "constructor, organiser, permanent persuader and not just a simple orator.....”. Dalam pola hidup partisipatif-empatik, para pendeta sebagai intelektual organik dapat mengembangkan pendidikan dan pelayanan pastoral pembebasan yang melibatkan komponen-komponen warga jemaat. Kependetaan menjadi fasilitator dan partisipator dalam gerakan pendidikan dan pelayanan pastoral yang menaruh keutamaan pada liberasi yang berakar dalam humanisasi manusia di tengah sistem sosial yang menindas dan menekan. 
Untuk itu, pelayanan pastoral tradisional yang berorientasi pada individu dan psiko-religius, tetapi mengabaikan aspek-aspek sosial, harus diarahkan ulang terlebih dahulu. Individualisme pelayanan pastoral patut diberi perimbangan korektif dengan pelibatan aspek-aspek sosial-kultural-politik-ekonomi dalam kerja-kerja pastoral. ${ }^{17}$ Stephen Pattison menegaskan, bahwa pelayanan pastoral harus memasukkan dan melibatkan analisis sosio-politik ke dalam teori dan praktik. ${ }^{18}$ Dengan begitu, dapatlah dikembangkan pelayanan pastoral yang layak bagi orang-orang yang menderita dan tertindas karena lokasi sosial mereka. Pattison menyampaikan beberapa prinsip dalam memikirkan ulang pelayanan pastoral, yakni analisis sosiopolitik, keberpihakan pada kaum tertindas, perubahan kesadaran, pengembangan aliansi, aksi sosial-politik berkelanjutan, dan perhatian kepada para individu dalam kaitannya dengan realitas-realitas sosial yang tidak adil.

Bertolak dari model pendidikan kaum tertindas yang diprakarsai oleh Paulo Freire, saya mencoba memberikan perspektif bagi pengembangan pastoral pembebasan atau pastoral kritis. ${ }^{19}$ Pada prinsipnya, model pelayanan pastoral pembebasan berakar di dalam penegakan dan pembelaan martabat kemanusiaan (humanisasi) serta bertujuan melawan proses-proses dehumanisasi masyarakat tertindas. Bagi Freire, humanisasi adalah proses perjuangan terus-menerus "becoming morefully human" dan merupakan ethical ideal. ${ }^{20}$ Bagi Freire, panggilan dan perjuangan untuk menjadi manusia yang makin penuh adalah esensi dari keberadaan kita sebagai manusia. Humanisasi adalah suatu panggilan (vacation) ontologis sekaligus historis. Ontologis artinya humanitas terberi dan terbawa sebagai pengalas kemenjadian keberadaan manusia. Dengan begitu, humanisasi juga adalah panggilan yang melekat dalam diri individu dan kolektif manusia. Sejarah menunjukkan bahwa perjuangan humanisasi ini berlangsung sepanjang kehidupan, berdasarkan refleksi kritis dalam dunia objektif relasi-relasi sosial.

Humanisasi berpusat pada conscientization, yakni proses dan usaha pengubahan kesadaran individu dan kolektivitas menuju kesadaran kritis. ${ }^{21}$ Proses yang terkait langsung dengan proses "belajar memahami kontradiksi sosial, politik dan ekonomi, serta mengambil tindakan untuk melawan unsur-unsur yang menindas dari realitas tersebut". ${ }^{22}$ Menurut Freire, kesadaran manusia memiliki tiga model level, yakni kesadaran magis, kesadaran naif, dan kesadaran kritis-transformatif. Kesadaran magis adalah model kesadaran masyarakat ketika mereka belum atau 
tidak mampu melihat kaitan satu faktor dengan faktor lain dari suatu fenomena atau masalah. Masyarakat tidak mampu melihat sebab-sebab struktural yang membentuk kondisi tertindas mereka. Kondisi bermasalah selalu dipahami dan diterima sebagai berada di luar atau di atas realitas objektif hidup sehari-hari. Mereka cenderung bersikap menerima nasib dan membisu (fatalisme). Cara berpikir siklis. sangat kuat dan cenderung mencari solusi dengan menggunakan cara-cara mistik.

Kesadaran naif adalah model kesadaran masyarakat yang cenderung mencari penyebab masalah mereka, yaitu diri mereka sendiri. Di sini penyebab masalah bukan kekuatan-kekuatan suprarealitas: tetapi manusia sendiri adalah akar permasalahan dalam masyarakat. Di sini kehidupan kaum penindas yang menjadi model atau tolok ukur. Oleh karena itu, kaum tertindas menyalahkan diri mereka karena tidak mampu hidup seperti para penindas atau tidak bisa memenuhi keinginan dan ukuranflikuran kaum penindas. Dalam model kesadaran ini, kaum tertindas lebih cenderung mengambil jalan melebur dengan kaum penindas, bekerja sama dan menjelma menjadi penindas baru. Kaum tertindas mengadopsi dan melanggengkan ideologi kaum penindas atau ideologi dominan.

Menurut Freire, kesadaran kritis adalah model kesadaran yang ditandai dengan penafsiran yang mendalam atas berbagai masalah-digantikannya penjelasan magis dengan penjelasan kausalitas; dengan mencoba penemuan-penemuan baru yang dihasilkan seseorang; dengan keterbukaan melakukan revisi; dengan usaha menghindari distorsi ketika memahami masalah dan menghindari pemutlakan konsep-konsep yang telah diterima sebelumnya ketika menganilisis masalah; dengan menolak sikap pasif; dengan mengemukakan pendapat; dengan mengedepankan dialog daripada polemik; dengan menerima pandangan tetapi bukan sekadar karena sifat kebaruannya, dan dengan keinginan untuk tidak menolak pandangan kuno hanya karena sifat kekunoannya-yakni dengan menerima apa yang benar menurut pandangan kuno dan baru. ${ }^{23}$

Kesadaran kritis membawa manusia kepada dua kondisi. Pertama, aktualisasi diri, yakni penegasan akan eksistensi subjektif diri dan penolakan diri untuk menjadi "inang benalu" bagi kaum penindas. Mereka sendiri akan terus hidup dalam kesadaran untuk tidak menjadi penindas atau bagian dari sistem yang menindas. Kedua, berusaha secara sadar dan empirik dalam gerakan transformasi sistem yang menindas dan tidak adil. Oleh karena itu, kesadaran ini disebut juga kesadaran kritis- 
transformatif. Dalam konteks ini, kesadaran diri sebagai entitas subjektif yang berpikir dan bertindak kritis-transformatif menegaskan peran subjektivitas mengubah dunia dan sejarah. ${ }^{24}$

Pembebasan yang berpusat dan bertujuan pada humanisasi dan liberasi melalui proses konsientisasi ini menjadi titik api dan penggerak dari pendidikan dan pelayanan pastoral kontekstual. Model pendidikan dan pelayanan pastoral pembebasan ini dilangsungkan dalam tiga poros karakter kritikal, dialogikal, dan praksikal dengan titik sentral perubahan kesadaran. Semua proses ini berlangsung dalam realitas interaksi sosial (sistem sosial) sehari-hari. ${ }^{25}$ Poros kritikal menegaskan bahwa peserta didik dan layanan pastoral adalah subjek-subjek yang berpikir dan mampu mengetahui serta memahami. Mereka dibawa untuk memahami secara mendalam pokok belajar dan masalah. Mereka dikondisikan untuk terlibat aktif dalam proses pengenalan masalah, analisis kritis masalah, penjelasan sebab-sebab dan akibat-akibat dari realitas yang mereka alami atau hadapi. Pendekatan yang digunakan di sini disebut sebagai problem-posing approach. ${ }^{26}$ Bertolak dari pengajuan atau perhadapan sebuah masalah, peserta diajak menganalisis. Masalahyang dikemukakan berasal dari lingkungan dan pengalaman hidup nyata para peserta.

Proses analisis kritikal atas masalah atau kondisi ini dilakukan melalui dialog-dialog terstruktur dan bermanfaat. Inilah yang dikategorikan sebagai poros dialogikal. Bagi Freire, jalan untuk mengetahuinya dapat ditemukan dalam relasirelasi dialogis-komunikatif dengan orang-orang lain (intercommunication). Dialog sejati dijangkarkan dalam sikap empati, yang dialiri oleh love, humility, hope, faith, andtrust di antara pihak-pihak yang terlibat dalam usaha pencarian bersama. ${ }^{27}$ Freire menegaskan keutamaan dialog dengan mengutip Karl Jaspers, demikian :

"Dialogue is the only way, not only in the Vital questions of the political order, but in all the expressions of our being. Only by Virtue of faith, however, does dialogue have power and meaning; by faith in man and his possibilities, by the faith that I can only become truly myself when other men also become themselves." 28

Dialog-dialog itu berlangsung dalam keterlibatan-keterlibatan praktis dalam pergulatan kehidupan sehari-hari para peserta. Bagi Freire, pengetahuan berasal dari momen-momen aktivitas manusia yang berusaha mentransformasi kondisi kehidupan sehari-hari mereka. ${ }^{29}$ Peserta didik dan partisipan layanan pastoral dibawa untuk 
mendalami persoalan hidup mereka. Diagram pemodelan pelayanan pastoral pembebasan atau kritis ditunjukkan seperti gambar di bawah ini.

\section{Kerangka Model Pendidikan/Pastoral Pembebasan}

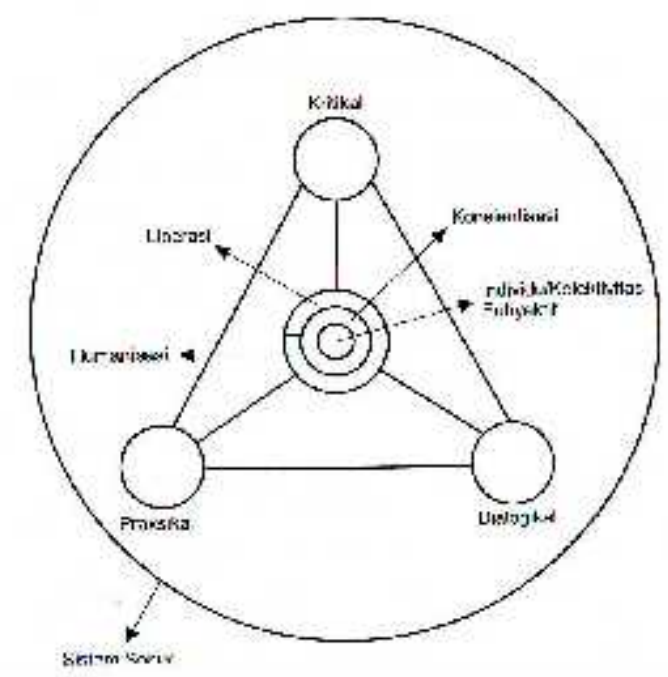

Dalam pelayanan pastoral pembebasan, partisipan, sebagai individu dan kolektivitas subjektif, dibawa untuk mendalami masalah mereka, seperti contoh kasus ketidakadilan yang dialami oleh Magda. Pada awalnya Undang-Undang Perlindungan Anak dipakai sebagai sarana penegur, tetapi dalam alur pelayanan pastoral itu digunakan sebagai alat analisis dan kritik situasi sosial. Melalui bantuan Undang-Undang Perlindungan Anak, mereka diajak menemukan dan memahami bahwa di balik pemaksaan terhadap Magda untuk menikah, terdapat begitu banyak tindakan kekerasan dan diskriminasi. penelantaran dll., yang dilakukan oleh para orangtua dan keluarga. bahkan masyarakat. Dari tahap analisis dan kritik sosial ini, para peserta didik dan partisipan pelayanan pastoral dibawa ke pendalaman melalui dialog-dialog terstruktur dan bertujuan. Dalam komunikasi dialogis ini, mereka dibawa kepada kesadaran kritis sebagai subjek subjek setara yang menggumuli dan merancang langkah-langkah transformatif atas masalah bersama ini. Semua pihak yang terlibat dalam semangat kebersamaan dan kesetaraan kini kembali ke dalam dunia praktis untuk melakukan tindakan-tindakan mentransformasi kondisi dan sistem sosial yang tidak adil dan dehumanitif, yang mereka sendiri telah ciptakan dan pelihara selama ini. 
Sejalan dengan itu, pastoral pembebasan dilaksanakan melalui institusi pendidikan internal gereja, seperti Sekolah Minggu dan Katekisasi. Anak-anak pun dibawa pada kesadaran kritis melalui pendidikan perhadapan-masalah (problemposing education). Anak-anak diajak mendialogkan masalah yang ditemukan dalam pengalaman keseharian hidup mereka. Melalui proses ini, mereka dibimbing untuk menganalisis dan mengungkap serta mengkritik kondisi sosial yang menjadi masalah mereka. Dengan begitu, mereka akan mencapai kesadaran kritis-transformatif terkait dengan kondisi atau masalah yang mereka hadapi. Anak-anak disadarkan pula untuk melakukan kritikdiri, terkait dengan realitas bahwa mereka pun ikut bertanggung jawab secara dini mencegah dan mengatasi permasalahan yang menghambat perkembangan mereka.

Catatan penting di sini terkait dengan fitrah pelayanan pastoral pembebasan. Pelayanan pastoral dan pendidikan ini merupakan upaya membangun komunitas basis keumatan sebagai konteks pastoral pembebasan yang melibatkan seluruh komponen atau unsur jabatan dan warga yang ada dalam jemaat lokal: pendeta, penatua, diaken, orangtua, keluarga-bahkan masyarakat dan pemerintah. Sejarah teologi pembebasan mencatat dengan terang bahwa kompleks atau konteks kelahiran teologi pembebasan adalah kehidupan kaum miskin dan terpinggirkan, yang membentuk komunitas-komunitas umat basis (20-30 keluarga). ${ }^{30}$ Komunitaskomunitas basis umat ini menjadi kompleks utama, tempat umat berkumpul melakukan devosi, membaca Kitab Suci dan berbagi pemahaman, serta pengalaman dan pergulatan hidup di bawah terang Firman Tuhan. Komunitas-komunitas basis menjadi kelompok-kelompok sel studi, pendidikan, dan pastoral kritis. Gutierrez menegaskan pentingnya komunitas basis sebagai setting asal usul teologi pembebasan ini :

"The historical womb from which liberation theology is the life of the poor, and, in particular, of the Christian communities that have arisen within the bossom of the present-day Latin American church. This experience is the setting in which liberation theology tries to read the word of God and be alert to the challenges that faith issues to the historical process in which the people engaged. ${ }^{31}$

Catatan historis ini mengingatkan kita akan pentingnya mengembangkan pengelompokan pelayanan warga jemaat yang telah ada sebagai komunitas basis bagi pengembangan pelayanan pastoral dan pendidikan pembebasan ini. Di sini, 
pendekatan atas-bawah dengan komunikasi satu arah harus diubah dengan pendekatan bawah-atas, dengan interkomunikasi individu dan kolektif serta berbasis pada pengalaman praktis kehidupan warga. Seluruh partisipan layanan pastoral dan pendidikan adalah agen-agen subjektif pengembang lingkungan pastoral dan pendidikan pembebasan. Itu berarti kependetaan menjadi salahsatuinisiator dan fasilitator sekaligus partisipan yang mengambil bagian dalam pengembangan lingkungan dan agen-agen pelayanan pastoral pembebasan mandiri.

\section{E. PENUTUP}

Pada tahun 1990, SouthEastAsia Graduate School of Theology Institute of Advanced Pastoral Studies pernah melaksanakan workshop dan penerbitan buku pastoral kontekstual berbasis Metode Studi Kasus. Tiga buku sempat diterbitkan, yaitu Studi Kasus Pastoral Wilayah Sumatra Utara, Nusa Tenggara Timur, dan Jawa. Paparan model ini terurai dalam empat tahap, yakni (1) Deskripsi masalah; (2) Analisis: mencari dan mengungkap penyebab-penyebab masalah: (3) Interpretasi: memahami masalah dan penyebab-penyebabnya di bawah sorotan dan arahan teologi, hukum, adat, dll., dan (4) Rencana aksi pastoral. Walaupun masih lebih merupakan bisnis akademik, metode studi kasus pastoral sudah membukajalan bagi pengembangan model kontekstual. Sayangnya, proyek ini terhenti tidak lama sesudah diluncurkan. Tampak bahwa gereja-gereja dan pendidikan tinggi teologi tidak melanjutkan proyek ini secara mandiri. Fenomena ini jelas menegaskan ulang sikap gereja-gereja dan lembaga-lembaga pendidikan teologi belum mempertimbangkan dan merancang baik praktik-praktik dan studi-studi pastoral secara serius.

\section{Endnotes:}

\footnotetext{
${ }^{1}$ Padahal para pelayan jemaat (pendeta) begitu kaya informasi dan pengalaman hidup bersama umat di kampong-kampung.

2 Konsep domestikasi di sini digunakan untuk menunjuk kepada kecenderungan mengurung atau membatasi kesadaran dan pemikiran warga jemaat dalam konteks hidup jemaat yang berdimensi spiritual dan individual semata terlepas dari konteks sistemik.

3 Gambaran kondisional ini dapat dilihat baik pada tataran praktis pelayanan maupun lingkup persidangan formal gereja. Semua berlangsung dalam langgam formalistik-proforma instutisional. Kondisi faktual ini antara lain terkait erat dengan karakter bergereja yang menganut model presbiterial sinodal, tetapi dalam praktiknya adalah sinodal-presbiterial. Secara historik, model bergereja ini diwariskan dari gereja-negara IndischeKerk pada zaman kolonial Belanda.

${ }^{4}$ Stephen B. Bevans, Model-Model Teologi Kontekstual (Maumere: Ledalero, 2002), 127-160.
} 
Bevans mendudukkan teologi pembebasan sebagai salah satu model teologi kontekstual. Ia memilih penyebutan teologi praksis, karena tekanannya pada praksis sebagai sumber dan tujuan berteologi. Lih. Gustavo Gutierrez, A Theology Of Liberation (Maryknoll, N.Y: Orbis Books, 1973); March H. Ellis \& Otto Maduro (eds.), Expanding The View: Gurtavo Gutierrez and the Future Of Liberation Theology (Maryknoll, N.Y.: Orbis Books, 1990); Stephen B. Bevans, Teologi dalam Perspektif Global :Sebuah Pengantar (Maumere : Ledalero, 2010).

${ }^{5}$ Dalam konteks pengalaman bergereja, $80 \%$ wilayah pelayanan GerejaProtestan Indonesia di Papua (GPI Papua) adalah kampung-kampung dan pedalaman di Papua.

${ }^{6}$ Bersumber dari wawancara dengan pendeta dan dua anggota Majelis Jemaat setempat. Peristiwa pastoral ini terjadi di tahun 2007/2008.

${ }^{7}$ Saat itu Pendeta belum menyebutkan referensi dasar hukum undang-undang.

${ }^{8}$ Program afirmatif adalah bagi strategi dari implementasi Undang-undang Nomor 21 Tahun 2001 tentang Otonomi Khusus bagi Provinsi Papua dan Papua Barat (Undang-Undang Nomor 35 Tahun 2008 tentang perubahan atas undang-undang Nomor 21 Tahun 2001) terkait dengan peningkatan mutu dan penyamaan kesempatan bagi Orang Asli Papua dalam bidang politik, Kepolisian, Pendidikan, Kependudukan, dan Ketanagakerjaan. Terkait dengan afirmasi pendidikan, penjelasan UU Nomor 21 tahun 2001 pasal 35 (3) menyatakan bahwa "Mengingat masih rendahnya mutu sumber daya manusia Papua dan pentingnya mengejar kemajuan di bidang Pendidikan, maka pemerintah daerah berkewajiban membiayai seluruh atau sebagian biaya pendidikan bagi putraputriAsli Papua pada semua jenjang Pendidikan”.

9 Data Jemaat GPI Papua Thomas Harada Tetar, Kampung Tetar, Teluk Patipi tahun 2012 menunjukkan bahwa 72,09\% warga jemaat berpendidikan SD dan tidak sekolah.

${ }^{10}$ Undang-Undang Perlindungan Anak Pasal 1 Ayat (1) menyebutkan secara jelas bahwa "Anak adalah seseorang yang belum berusia 18 (delapan belas) tahun, termasuk anak yang masih dalam kandungan.

${ }^{11}$ Basis hukum terkait hak asasi dan pelindungan anak tertuang dalam UU RI Nomor 23 tahun 2002 tentang Perlindungan Anak dan UU RI Nomor 35 Tahun 2014 tentang Perubahan atas UndangUndang Nomor 23 Tahun 2002 tentang Pelindungan Anak.

${ }^{12}$ Johan Galtung menjelaskan bagaimana produk-produk kebudayaan seperti ideologi, bahasa, agama, seni dan ilmu pengetahuan dapat digunakan untuk melegitimasi praktik kekerasan baik secara langsung (fisik) mau pun struktural (Sistem Sosial). Lebih jauh lihat karya-karya Johan Galtung, 'Cultural Violence.' Journal of Peace Research, Vol.27, No.3 (1990), 291; Peace by Peaceful Means: Peace and Conflict, Development and Civilization (London: Sage, 1996), h.196-210; 'Violence, Peace and Peace Research', Journal of Peace Research, vol. 6, no. 3, 1969, h. 167-191.

${ }^{13}$ Istilah absent digunakan untuk menggambarkan eksistensi kaum miskin oleh Gustavo Gutierrez "Expanding The View" dalam Marc H. Ellis and Otto Maduro (eds.), Expanding View - Gustavo Gutierrez and the Future of Liberation Theology (Maryknoll, N.Y.: Orbis Book, 1990), h. 6.

${ }^{14}$ Peristiwa ini disebut irruption of the poor, lihat Pedro Casaldaliga and Jose Maria Vigil, The Spirituality of Liberation (Maryknoll, N.Y.: Orbis Book, 1994).

${ }^{15}$ Kata "Solidaritas" berasal dari in solidum yang berarti "bersama berjalan memasuki dan menghadapi tantangan serta membangun harapan". Pilihan Etis dan praksis gereja ini dikenal dengan ungkapan penting yang menjadi prinsip teologi pembebasan, yakni preferential option for the pooratau yang lebih luas option for the masses of the people.

${ }^{16}$ Antonio Gramsci, Selection from the prison Notebooks (New York : International Publisher, 1971), 10; Roger Simon, Gramsci's Political - An Introduction (London : Elecbook, 1997), 112-113.

${ }^{17}$ Lihat antara lain beberapa artikel dalam David Willows and ]ohn Swinton (eds), Spiritual Dimensions of Pastoral Care: Practical Theology in a Multidiciplinary Context (London and Philadelphia: ]essica Kingsley Publisher, 2004): Alastair Campbell, "The Politics of Pastoral Care", 158-169; Michael Wilson, "Personal Care and Poltical Action", 170-178; Ryan LaMothe, "A Modest Proposal: A Pastoral Political Theology Pastoral Psychology" (2014) 63:375-391. Juga pada Proyek Studi Kasus Pastoral yang pernah dikembangkan melalui workshop dan penerbitan beberapa buku di Indonesia pada tahun 1990 oleh SEAGST Institute of Advanced Pastoral Studies untuk wilayah Sumatra Utara, Nusa Tenggara Timur, dan ]awa. Sayangnya, proyek penting ini telah berhenti.

${ }^{18}$ Stephen Pattison, Pastoral Care and Liberation Theology (Cambridge: Cambridge University Press, 1994). 
${ }^{19}$ Lihat Paulo Freire, Pendidikan Kaum Tertindas (Jakarta : LP3ES, 2011); Paulo Freire, Education for Critical Consciousness (London and New York : Continuum, 2005).

${ }^{20}$ Peter Roberts, Education, Literacy, and Humanization - Exploring the Work of Paulo Freire (Westport, Connecticut ; London : Bergin and Garvey, 2000), 41-43.

${ }^{21}$ William A. Smith, Conscientizacao :Tujuan Pendidikan Paulo Freire (Yogyakarta : Pustaka Pelajar, 2008).

${ }^{22}$ Freire, Op.Cit., 2.

${ }^{23}$ Diambil dari William A. Smith, Op.Cit., 80-81; Roberts, Op.Cit., 139.

${ }^{24}$ Kesadaran diri dan tindakan subjektif menjadi sentral penggerak. Freire, Pendidikan Kaum Tertindas, 22, menyatakan, "Menolak pentingnya peran subjektivitas dalam proses mengubah dunia dan sejarah adalah naif dan menyederhanakan persoalan. Sikap demikian sama saja dengan membenarkan sesuatu yang tidak mungkin: sebuah dunia tanpa manusia. Sikap objektivistik seperti ini adalah sikap yang sama sederhananya dengan subjektivisme, yang membenarkan postulat adanya manusia tanpa suatu dunia."

${ }^{25}$ Dalam pandangan teori sosial strukturasi oleh Anthony Giddens, Theory of Structuration (Berkeley and Los Angeles: University of California Press, 1986), reproduksi sosial berlangsung melalui praksis para partisipan dalam sistem sosial atau interaksi sosial sehari-hari. Pada satu sisi, individu dan kolektivitas dibentuk oleh struktur sosial-budaya di mana mereka hidup. Pada sisi lain, melalui praksis sosial, mereka juga merekonstruksi struktursosial-budaya. Proses dualitas-strukturasi ini berlangsung terus dalam ruang dan waktu.

${ }^{26}$ Pendekatan perhadapan-masalah ini merupakan koreksi kritis terhadap pendidikan model banking yang dibangun dalam konteks relasi subjek-objek guru dan peserta didik atau layanan; komunikasi non-dialogis, satu arah tanpa melibatkan peserta didik sebagai subyek sadar. Tekanan utama diberikan pada transfer pengetahuan otoritatif dari guru kepada peserta didik, sehingga nuansa indoktrinasi mengemuka.

${ }^{27}$ Paulo Freire, Op.Cit., 40.

${ }^{28}$ Ibid

${ }^{29}$ Roberts, Op.Cit., 39.

${ }^{30}$ Dijelaskan secara singkat dan baik oleh Penny Lernoux, "The Birth of Liberation Theology" dalam Ellis and Maduro, Expanding The View, 39-46.

${ }^{31}$ Gutierrez, Op.Cit., 19-20.

\section{DAFTAR PUSTAKA}

Bevans, Stephen B. Model-Model Teologi Kontekstual. Maumere: Ledalero, 2010. Teologi dalam Perspektif Global: Sebuah Pengantar. Maumere:

Ledalero, 2002.

Casaldaliga, Pedro, and Jose, Maria Vigil. The Spirituality of Liberation. Maryknoll, N.Y.: Orbis Book, 1994.

Ellis, March H., and Otto, Maduro, ed. Expanding The View: Gustavo Gutierrez and the Future of Liberation Theology. Maryknoll, N.Y.: Orbis Books, 1990.

Freire, Paulo. Education for Critical Consciousness. London and New York: Continuum, 2005. Pendidikan Kaum Tertindas. Jakarta: LP3ES. 2011. 
Galtung, Johan. Peace by Peaceful Means: Peace and Conflict, Development and Civilization. London: Sage. 1996.

Giddens, Anthony. Theory of Structuration. Berkeley and Los Angeles: University of California Press, 1986.

Gramsci, Antonio. Selection from the Prison Notebook: New York: International Publishers, 1971.

Gutierrez, Gustavo. A Theology of Liberation. Maryknoll, N.Y.: Orbis Books, 1973.

LaMothe, Ryan. "A Modest Proposal: A Pastoral Political Theology." In Pastoral Psychology 65, 375-391. (1973.)

Pattison, Stephen. Pastoral Care and Liberation Theology. Cambridge: Cambridge University Press, 1994.

Roberts, Peter. Education, Literacy, and Humanization - Exploring the Work of Paulo Freire. Westport, Connecticut ; London : Bergin and Garvey, 2000.

Simon, Roger. Gramsci’s Political-An Introduction, London Elecbook, 1997.

Smith, William A. Conscientizatcao; Tujuan Pendidikan Paulo Freire. Yogyakarta : Pustaka Pelajar, 2008.

UU RI Nomor 23 Tahun 2002 Tentang Perlindungan Anak.

UU RI Nomor 35 Tahun 2014 Tentang Perubahan atas Undang-Undang Nomor 23 Tahun 2002 tentang Perlindungan Anak.

Willows, David, and John, Swinton, ed. Spiritual Dimensions ofPartoral Care: Practical Theology in a Multidiciplinary Context. London and Philadelphia: Jessica Kingsley Publisher, 2004.. 